DOI: http://dx.doi.org/10.5007/2175-7941.2014v31n1p208

\title{
Informes" Aprendendo ciência e sobre sua natureza: abordagens históricas e filosóficas ${ }^{+}$
}

O livro Aprendendo ciência e sobre sua natureza: abordagens históricas e filosóficas foi organizado por Cibelle Celestino Silva, do Instituto de Física daUSP de São Carlos (IFSC-USP), e Maria Elice Brzezinski Prestes, do Instituto de Biociências da USP (IB-USP).

A obra contém uma coletânea de 38 trabalhos da interface entre história, filosofia e sociologia da ciência e o ensino de ciências, relacionados a uma ampla gama de temas que refletem a riqueza de pesquisas desenvolvidas no Brasil e no exterior. Escritos em português, espanhol e inglês, os capítulos do livro discutem, ao longo das suas 562 páginas, seis grandes temas distribuídos em episódios históricos, tópicos de filosofia e sociologia da ciência, natureza da ciência, aplicações em sala de aula, materiais instrucionais, formação de professores e currículo. O conjunto fornece perspectivas teóricas e práticas diversificadas para a pro-

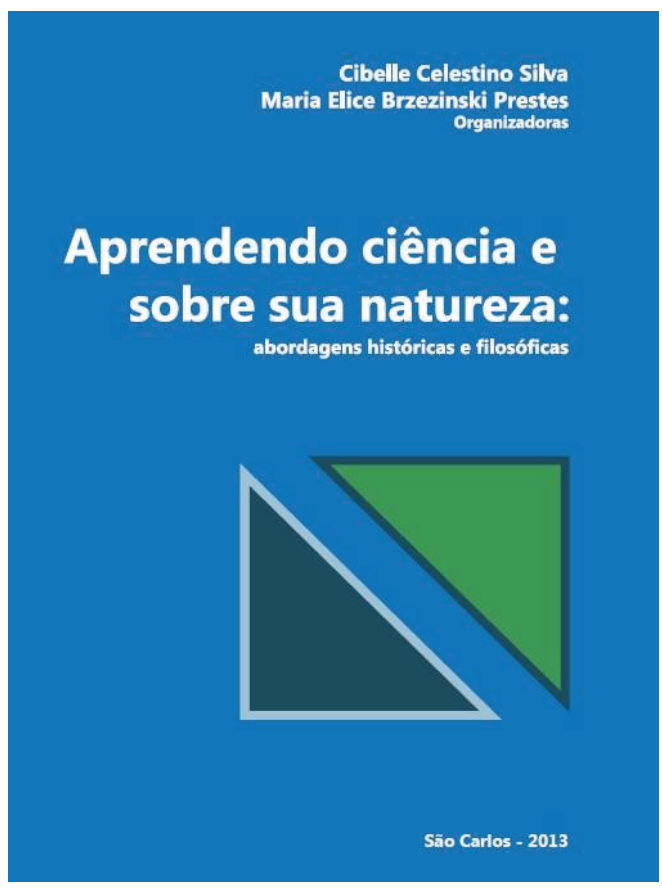

\footnotetext{
* Recebido: março de 2014.

Aceito: março de 2014.

Learning Science and its nature: historical and philosophical approach
} 
moção da utilização da História, Filosofia e Sociologia da Ciência na formação em ciências, no Ensino Básico e Superior.

\section{Sumário}

I. Episódios históricos

II. Tópicos de Filosofia e Sociologia da Ciência

III. Natureza da Ciência

IV. Aplicações em sala de aula

V. Materiais instrucionais

VI. Formação de professores e currículo

Maria Elice de Brzezinski Prestes

Laboratório de História da Biologia e Ensino

Departamento de Genética e Biologia Evolutiva - USP 